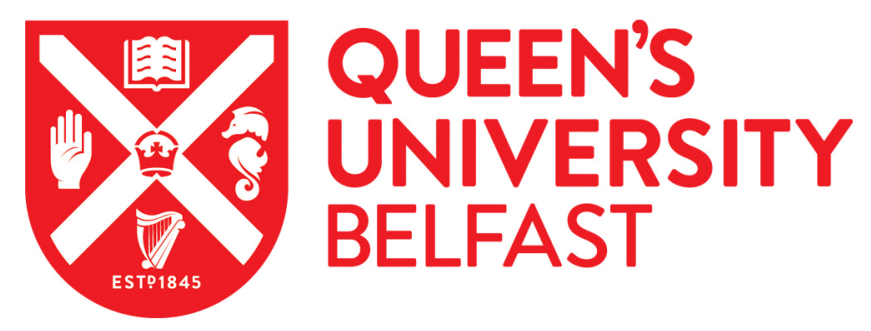

\title{
The Effect of Data Breach Announcements Beyond The Stock Price: Empirical Evidence on Market Activity
}

Rosati, P., Cummins, M., Deeney, P., Gogolin, F., Van der Werff, L., \& Lynn, T. (2017). The Effect of Data Breach Announcements Beyond The Stock Price: Empirical Evidence on Market Activity. International Review of Financial Analysis. https://doi.org/10.1016/j.irfa.2017.01.001

Published in:

International Review of Financial Analysis

Document Version:

Peer reviewed version

Queen's University Belfast - Research Portal:

Link to publication record in Queen's University Belfast Research Portal

Publisher rights

(C) 2017 Elsevier Ltd. This manuscript version is made available under the CC-BY-NC-ND 4.0 license http://creativecommons.org/licenses/by$\mathrm{nc}-\mathrm{nd} / 4.0 /$ which permits distribution and reproduction for non-commercial purposes, provided the author and source are cited.

\section{General rights}

Copyright for the publications made accessible via the Queen's University Belfast Research Portal is retained by the author(s) and / or other copyright owners and it is a condition of accessing these publications that users recognise and abide by the legal requirements associated with these rights.

Take down policy

The Research Portal is Queen's institutional repository that provides access to Queen's research output. Every effort has been made to ensure that content in the Research Portal does not infringe any person's rights, or applicable UK laws. If you discover content in the Research Portal that you believe breaches copyright or violates any law, please contact openaccess@qub.ac.uk. 


\section{Accepted Manuscript}

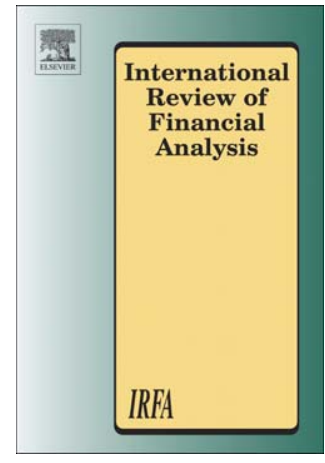

PII:

S1057-5219(17)30002-9

DOI:

doi: 10.1016/j.irfa.2017.01.001

Reference:

FINANA 1071

To appear in: $\quad$ International Review of Financial Analysis

Received date: 9 August 2016

Revised date: $\quad 14$ December 2016

Accepted date: 12 January 2017

Please cite this article as: Rosati, P., Cummins, M., Deeney, P., Gogolin, F., van der Werff, L. \& Lynn, T., The effect of data breach announcements beyond the stock price: Empirical evidence on market activity, International Review of Financial Analysis (2017), doi: $10.1016 /$ j.irfa.2017.01.001

This is a PDF file of an unedited manuscript that has been accepted for publication. As a service to our customers we are providing this early version of the manuscript. The manuscript will undergo copyediting, typesetting, and review of the resulting proof before it is published in its final form. Please note that during the production process errors may be discovered which could affect the content, and all legal disclaimers that apply to the journal pertain. 


\title{
The Effect of Data Breach Announcements Beyond The Stock Price: Empirical Evidence on Market Activity
}

\author{
Pierangelo Rosati* \\ Mark Cummins* \\ Peter Deeney* \\ Fabian Gogolin* \\ Lisa van der Werff*
}

Theo Lynn*

\begin{abstract}
Extending the literature that has focused thus far on stock price impact, this study investigates the effect of data breach announcements on market activity, specifically through the response of the bid-ask spread and trading volume. We investigate data breach announcements as a potential source of asymmetric information and provide a new dimension to the ongoing debate on market efficiency. Adopting an event study methodology on a sample of 74 data breaches from 2005 to 2014, we find that data breach announcements have a positive short-term effect on both bid-ask spread and trading volume. The effect is only evidenced however on the day of the event, with market efficiency ensuring a quick return to normal market activity. No abnormal trading activity emerges before announcements, so there is no evidence in our study that these types of events are being exploited by informed market participants. The magnitude of event day effects is found to be more pronounced for large breaches, and when the breach involves lost devices.
\end{abstract}

Keywords: Data Breach, Stock Market, Bid-Ask Spread, Trading Volume, Event Study. JEL Codes: G12, G14, O30

* DCU Business School, Dublin City University, Dublin 9, Ireland. 


\title{
The Effect of Data Breach Announcements Beyond The Stock Price: Empirical Evidence on Market Activity
}

\begin{abstract}
Extending the literature that has focused thus far on stock price impact, this study investigates the effect of data breach announcements on market activity, specifically through the response of the bid-ask spread and trading volume. We investigate data breach announcements as a potential source of asymmetric information and provide a new dimension to the ongoing debate on market efficiency. Adopting an event study methodology on a sample of 74 data breaches from 2005 to 2014, we find that data breach announcements have a positive short-term effect on both bid-ask spread and trading volume. The effect is only evidenced however on the day of the event, with market efficiency ensuring a quick return to normal market activity. No abnormal trading activity emerges before announcements, so there is no evidence in our study that these types of events are being exploited by informed market participants. The magnitude of event day effects is found to be more pronounced for large breaches, and when the breach involves lost devices.
\end{abstract}

Keywords: Data Breach, Stock Market, Bid-Ask Spread, Trading Volume, Event Study.

JEL Codes: G12, G14, O30

\section{Introduction}

In the last decade the amount of data collected, processed and stored by firms has grown exponentially and this tendency will probably continue in the next years (LaValle et al., 2011). Data analytics has been, and still is, reshaping many industries (Minelli et al., 2012) e.g. healthcare, banking, finance and media and communications, but it also raises a firms' activity risk (Chen et al., 2012). Stored data are usually highly sensitive and extremely valuable thus they attract the attention of cyber criminals; as a result, the number and the cost of incidents have grown significantly in the last decade (Ponemon, 2015; Verizon, 2015) and cyber security has become a key issue for both managers and regulators (Deloitte, 2016; George, 2016; Hulme, 2015; SEC, 2014, 2016).

Within this context, we analyse the impact of data breach announcements on market activity, in order to investigate the presence of informed trading and test for market efficiency around this new corporate event type. We extend the existing literature that to 
date has focused on stock price impact and the effect on corporates. We move attention to the broader issue of market activity and address concerns of relevance to the wider investment community. A number of contributions are made.

First, we analyse bid-ask spread determination through analysing data breach announcements as a potential source of asymmetric information between market dealers and uninformed liquidity traders, and informed traders. A myriad of corporate events have been studied to date including earnings announcements (Affleck-Graves et al., 2002; Krinsky and Lee, 1996; Lee et al., 1993; Venkatesh and Chiang, 1986); auditor change (Hagigi et al., 1993); stock repurchases (Franz et al., 1995); management earnings forecasts (Coller and Yohn, 1997); bankruptcy (Frino et al., 2007) and merger and acquisition (Chan et al., 2015). Heretofore however, market activity around data breach announcements has not been studied. Furthermore, data breaches have particular characteristics compared to other corporate events. Data breach events are truly unexpected, both in terms of timing and frequency of occurrence (Ko et al., 2009), which is an advantage in a study like this. Many of the corporate events studied to date are expected, to varying degrees, and primary interest lies in deviations from market expectations. Mergers and acquisitions come closest to unexpected events (Augustin et al., 2015), but are not truly unexpected given the protracted nature of the associated negotiations and strategic manoeuvrings by the players involved. Data breaches therefore present a fresh testing ground to analyse market behaviour.

Second, we conduct a round of testing on trading volume as an alternative measure of market activity, to investigate whether there is consistency with our findings on the bidask spread. While the effect of (expected or unexpected) corporate events on pricing is unambiguous, namely the widening of the bid-ask spread to protect market dealers from uninformed traders, the effect on trading volume is, to the contrary, ambiguous and more nuanced. One school of thought suggests that trading volume may increase in the presence of asymmetric information, resulting from the exogeneity and inelasticity of uninformed liquidity trading (Kyle, 1985; Chae, 2005), while another suggests that trading volume may decrease in the presence of asymmetric information, where it is assumed in this case that liquidity traders have timing discretion (Admati and Pfleiderer, 1988; Foster and Viswanathan, 1990; Chae 2005). Either way, the suggested abnormal volume effects correspond to informed traders optimizing their advantage over market dealers and uninformed liquidity traders.

Third, we examine the duration of abnormal trading activity, if it exists, post data breach announcements. How fast the market absorbs new information is at the core of 
the Efficient Market Hypothesis (Fama, 1970). Other corporate events that have been analysed in the past show mixed evidence as to whether markets are efficient or not. Our analysis sheds new light on this topic of market efficiency, showing to what extent the market monitors and responds to emerging news on the modern corporate phenomenon of data breaches.

Finally, we examine the factors that may determine the magnitude and direction of impacts on market activity from data breach events. Informed by the literature, we consider the size of the breach as a possible factor, positing that impacts are more pronounced for larger breaches relative to smaller breaches. We also examine whether the type of breach that has occurred is a factor, and whether the consequences of a data breach depend on the industry in which a breached firm operates. Analysing the impact of data breach announcements on market activity across these dimensions adds additional insight to the existing evidence on stock price response.

Using a dataset of 74 data breaches, involving US publicly traded firms over the period 2005 to 2014, we assess the impact of the associated announcements on market activity. We find evidence of a positive short-term impact of data breach announcement on bidask spread and trading volume. The effect is only evidenced however on the day of the event, with market efficiency ensuring a quick return to normal market activity. No abnormal trading activity emerges before announcements, providing evidence that these types of events are not being exploited by informed market participants. The effect on bid-ask spread is evidenced to be more pronounced for events that involve a large number of records or that involve lost devices; the effect on trading volume is evidenced to be more pronounced for larger firms and for events that involve lost devices.

The rest of the paper is organised as follows. Section 2 provides a review of the relevant literature and formally states the research hypotheses. Section 3 presents the data. Section 4 discusses the research design. Section 5 presents the results of the empirical analysis. Section 6 reports some important concluding remarks.

\section{Literature review and hypotheses development}

The number of incidents affecting information systems is growing every year and actual and emerging trends such as social media, cloud computing, mobile devices and big data exacerbate this issue (Abbasi et al., 2016; Romanosky et al., 2014). Goldstein et al. (2011) classify such events into two main categories, namely data-related and functionrelated events. A data-related event is any threat to the confidentiality of data assets that 
can result in the disclosure, misuse, or destruction of these assets. A function-related event, instead, is any threat to the availability or to the integrity of functional information systems (that may eventually affect data assets). Although both event types impose significant costs to the affected companies, such costs are due to different causes and are spread differently over time. Short-term costs of data events are mainly related to investigation and remediation activities, legal advisory and fines, while longterm costs are related to loss of present and future revenues and deterioration of customers' or partners' trust (Cavusoglu et al., 2004). Short-term costs of function events include losses in terms of lost productivity and lost transactions (Paquette et al., 2010), as well as remediation costs that can vary depending on the type of incident (Charette et al., 1997; Dennis et al., 2015), while long-term costs are related to loss of growth opportunities (Bharadwaj et al., 1999) and inefficiencies (Arend, 2004). Regardless of the event type, a breach imposes significant costs on the affected firm. Famous cases of data and function events are ChoicePoint and Nasdaq. In early 2006, ChoicePoint paid a $\$ 10$ million fine as a result of its breach and another $\$ 5$ million to a fund to compensate affected individuals (FTC, 2009). In 2012, the websites of exchanges Nasdaq and BATS suffered a 24-hour attack that led to intermittent service disruptions (Krudy, 2012) and to a 12 percent decrease in daily US stock trading activity (Savitz, 2012).

Given that the overall cost of a breach includes many different components, and that such components span over different periods of time, the quantification of such a cost is extremely complex. The change in stock price following the data breach announcement is often adopted as a proxy. This assumption is based on the semi-strong Efficient Market Hypothesis as stated by Fama (1970). Following this hypothesis, a stock price incorporates all public information and all future expected firm cash flows. The majority of existing empirical studies focus on the wider category of security breaches and they analyse typically small samples. Campbell et al. (2003) analyse 43 events from 1995 to 2000 and they find no statistically significant abnormal returns except for 11 events, which involve confidential data, where stock prices drop by 5.5 percent over a three-day period around the announcement. Garg et al. (2003) examine 22 information security incidents from 1996 to 2002 and they find an average share price decline of 5.3 percent over a three-day period following the announcement. Hover and D'Arcy (2003) examine 23 denial-of-service (DOS) attacks between 1998 and 2002, and they show no statistically significant stock price response. Cavusoglu et al. (2004) analyse 66 events from 1996 to 2001 and they provide evidence of an average abnormal return of - 
2.1 percent over a two-day window following the event. They also demonstrate that the breach cost is higher for those firms that rely only on the Internet for doing business, and that this cost is not significantly different across breach types.

The conflicting results of these studies may be due to event choice since they typically analyse security breach events or a mixture of security and data breaches. Such events are different from each other and some of them may have non-significant economic impact. To the extent of our knowledge, only Gatzlaff and McCullough (2010) examine data breach events as defined above. Their sample includes only events that involve employees' or customers' personal information. Their analysis of 77 events from 2004 to 2006 shows a decline in share price of 0.84 percent over a two-day time window starting from the announcement day and that the breach effect is more significant in the most recent period of the analysis.

While the impact of breach announcements on financial markets is garnering greater attention, existing studies focus solely on price reaction (i.e. abnormal returns). None have investigated other important aspects of trading activity, such as the bid-ask spread and trading volume. Bid-ask spread and trading volume are well-established proxies to detect informed trading and allow for an examination of the effect of temporary information advantages that informed investors might hold (Chae, 2005; Pinder, 2003). We are motivated to take the dual approach of analysing bid-ask spread and trading volume together in our study given that data breach events have not been considered to date in this context. While the trading volume analysis provides a robustness check to the bid-ask spread analysis that we perform, informed trading effects on trading volume are more nuanced and insightful. While the widening of the bid-ask spread to protect market dealers in the presence of informed trading is an expected effect, trading volume may either increase or decrease depending on the market reaction to informed trading; the former case corresponding to exogeneity and inelasticity of uninformed liquidity trading (Kyle, 1985; Chae, 2005) and the latter case corresponding to the case of timing discretion on the part of uninformed liquidity traders (Admati and Pfleiderer, 1988; Foster and Viswanathan, 1990; Chae 2005).

\subsection{Hypothesis development}

According to previous studies, the bid-ask spread is a function of the costs related to the dealers' order processing, inventory-holding, and adverse selection (Affleck-Graves et al., 2000; Aitken et al., 2004; Pinder, 2003). The early microstructure literature 
emphasises the first two components of the spread, predicting that the spread increases with price volatility and decreases with price level, trading volume and competitive pressure (Benston and Hagerman, 1974; Demsetz, 1968). Later, Copeland and Galai (1983) and Glosten and Milgrom (1985) incorporated informed trading risk as a spread component. These models are based on the idea that market dealers face two types of traders: uninformed liquidity traders and informed traders. While liquidity traders trade on public information, informed traders trade on private information and, therefore, they buy (sell) only when the stock is undervalued (overvalued). As a consequence, market dealers always lose against informed traders and thus they have to increase the spread to liquidity traders in order to recover their losses to informed traders. For this reason, it is predicted that the spread is positively related to the proportion of informed trading.

A large number of studies address bid-ask behaviour around company announcements, such as earnings announcements (Affleck-Graves, et al., 2002; Bushee et al., 2010; Krinsky and Lee, 1996; Lee, et al., 1993; Venkatesh and Chiang, 1986), auditor change (Hagigi, et al., 1993), stock repurchases (Franz, et al., 1995), management earnings forecasts (Coller and Yohn, 1997), bankruptcies (Frino, et al., 2007) and mergers and acquisitions (Chan, et al., 2015). However, to our knowledge, this is the first study that investigates the impact of data breach announcements on the bid-ask spread. A data breach announcement should be completely unexpected (Ko et al., 2009). Security breach notification laws (SBNLs) passed at state level in the US require firms to disclose data breaches promptly in order to limit possible harm (Romanosky et al., 2014). Furthermore, the laws require confidentiality to be maintained around data breaches in the interim (Winn 2009), in principle allowing no scope for abnormal trading prior to the announcement. This implies that no information asymmetry, and therefore no abnormal trading activity, should be detected before the announcement (Frino, et al., 2007). Instead, on the announcement day, and possibly in the days following the announcement, an abnormal level of spread may be expected due to the information shock, which creates higher uncertainty and, therefore, increases the risk of exposure to informed trading. These considerations lead to the following research hypotheses:

H1(a): bid-ask spread does not increase before the announcement of a data breach;

H1(b): a data breach announcement increases the bid-ask spread. 
Rejection of $H 1(a)$ would signal a response of market dealers to abnormal trading activity in the days leading up to data breach announcements. It is this situation that would point to the use of non-public information around data breach events by informed traders. On the other hand, acceptance of $H 1(b)$ would signal the usual response of market dealers in widening bid-ask spreads over fears of losses to informed traders. Our examination of data breach announcements over a defined event window provides important insights into how quickly information around data breach events gets assimilated by equity markets; reflected in the narrowing of the bid-ask spread to normal trading levels.

A second way to consider the presence of informed trading is analysing trading volume. Trading volume in financial markets plays a critical role since it facilitates the price discovery process, enables investors to share financial risks, and ensures that corporations can raise funds needed for investment (Chae, 2005). The effect of informed trading on trading volume is ambiguous. One school of thought suggests that trading volume may increase in the presence of asymmetric information, resulting from the exogeneity and inelasticity of uninformed liquidity trading, while another suggests that trading volume may decrease in the presence of asymmetric information, where it is assumed in this case that liquidity traders have timing discretion (Chae, 2005). Milgrom and Stokey (1982), Black (1986) and Wang (1994) show that uninformed traders participate less in the market when there is a higher possibility of trading with informed traders in order to avoid losses. Chae (2005) confirms this finding comparing trading volume around scheduled (i.e. earnings) and unscheduled (i.e. acquisition, target, bond rating change) announcements. The author demonstrates that trading volume decreases before scheduled announcements due to information asymmetry.

Given that firms should announce a data breach promptly under SBNLs requirements in order to limit possible harm (Romanosky et al., 2014), such events should be unanticipated and no abnormal trading volume should appear before the announcement (Chae, 2005). Abnormal trading volume, instead, may emerge after the announcement due to the information release. In addition, given that a data breach announcement is typically anything but neutral, we predict that the trading volume would be higher than usual since traders will be inclined to sell to avoid possible losses. We therefore propose the following hypotheses:

H2(a): trading volume does not increase before the announcement of a data breach; 
H2(b): a data breach announcement increases trading volume.

Rejection of $H 2(a)$ would again signal the presence of informed trading prior to the data breach announcements, while acceptance of $H 2(b)$ would signal a response of market dealers to the potential for losses to informed traders.

To expand the analysis further, we consider next the factors that may determine the magnitude and direction of impacts on market activity from data breach events. Although a data breach is usually a negative event for effected firms and their shareholders, the size of the breach (i.e. number of records breached) may exacerbate the consequences. Gatzlaff and McCullough (2010) include this factor in their model but they do not find any significant effect on returns. Notwithstanding this, larger breaches should be associated with greater implicit and explicit costs and we expect that they have a larger impact than more minor events both on spread, since they create higher uncertainty, and trading volume, since they may cause a more significant drop in share price and investors may be more willing to sell stocks to avoid significant losses. We therefore consider the following additional hypotheses:

H3(a): The impact of data breach announcements on bid-ask spread is positive and more pronounced for larger than for smaller breaches;

H3(b): The impact of data breach announcements on trading volume is positive and more pronounced for larger than for smaller breaches.

Existing studies argue that the impact of a breach announcement depends also on the type of breach that occurred. Campbell et al. (2003) divide their sample based on the confidentiality or non-confidentiality of exposed information and demonstrate that breaches involving confidential data have a negative and significant effect on a firm's value. However, Cavusoglu et al. (2004) distinguish between events whose objective is to compromise data availability and all the others but they do not find any significant difference. Furthermore, Gatzlaff and McCullough (2010) classify the events in their sample as active, stolen or lost, but find no significant differential impact. Given the mixed evidence, we state our research hypotheses in the following null form:

H4(a): The impact of data breach announcements on bid-ask spread does not depend on breach type;

H4(b): The positive impact of data breach announcement on trading volume does not depend on breach type. 


\section{Data}

In this paper we adopt an event study methodology to investigate the impact of data breach announcements on two dimensions of market activity: the bid-ask spread and trading volume. We build our sample starting from a list of breaches, which occurred from January 2005 to December 2014, as compiled by Privacy Rights Clearinghouse. ${ }^{1}$ The initial list consisted of 4,483 events, of which we excluded 4,152 for being related to non-publicly traded firms. For the remaining sample of 331 events, we searched the LexisNexis database for possible confounding events ${ }^{2}$ during the seven days before the announcement and 58 events were excluded on this basis. We also checked whether the events in our sample were reported in newspapers before the official announcement date. It turned out that 26 events matched this criterion and in these cases we adjusted the event date back to reflect the date of the first newspaper article. From the remaining 273 events, we excluded 149 events with unknown number of records breached in order to ensure we focused only on events that can be classified as a data breach. Events with undisclosed number of records, indeed, might be security breach events. As such, they tend to have a marginal impact on the affected firms in terms of fines and reputation damage, and might bias the results. We also deleted 14 further events on the basis that the same company had a breach during the 132 days before the announcement; this was necessary to ensure that the estimation period of the analysis is not affected by previous events. As a final step, we excluded another 37 events because of missing data. Our final sample therefore consists of 74 events $^{3}$. Table 1 summarises the sampling process. Table 2 provides relative frequencies of events over time, while Table 3 reports the number of events per industry.

We retrieved daily equity data (i.e. closing price, high price, low price, volume and common shares outstanding) on the associated companies from Thomson Reuters Datastream. The ownership structure data was obtained from BoardEx. It is important to note that while we have 74 data breaches, these relate to 62 individual companies.

\section{Insert Table 1 here}

\footnotetext{
${ }^{1}$ Privacy Rights Clearinghouse is a California based nonprofit corporation. The organization looks to, among other activities, identify trends in privacy protection and communicate its findings to advocates, policymakers, industry, media and consumers. Detailed information on data breaches is available at http://www.privacyrights.org/data-breach. We use this source to identify the data breach events studied in this paper.

${ }^{2}$ Following Hollander and Prokop (2015), we considered earnings announcements, merger and acquisitions announcements, capital increases, investment or disinvestments announcements, public offerings, rating actions, and restructuring announcements as confounding events.

${ }^{3}$ The limited sample size reflects the data availability and the need to apply adequate filters in order to reduce possible noises. Both the sampling criteria and the size of our sample are in line with previous studies on the same topic (Cavusoglu et al. 2004; Gatzlaff and McCullogh 2010; Gordon et al. 2011).
} 


\section{Insert Table 2 here \\ Insert Table 3 here}

\section{Research design}

In performing our event study, we set a 126-day estimation window $(-132,-6)^{4}$, while our analysis period consists of 11 trading days centred on the event day $(-5,+5)$. Following McLean and Pontiff (2016), Koch et al. (2016), and Easley et al. (2016), we estimate the daily bid-ask spread as proposed by Corwin and Schultz (2012). Corwin and Schultz (2012) provide a way to estimate the bid-ask spread from daily high and low prices. Their simulation reveals that the correlation between the spread estimated through such a methodology and the spread using trades and quotes data is about 0.9. Other low-frequency estimation methodologies include Roll (1984), Lesmond et al. (1999), and Holden (2009). However, Corwin and Schultz (2012) demonstrate that their model performs better than others. In our estimation, we consider the adjustments for overnight price changes and negative spread estimates as suggested by the authors.

We then estimate the abnormal bid-ask spread as suggested by Bushee et al. (2010), Blankerspoon et al. (2014) and Michels (2016):

$$
\begin{gathered}
A B A S_{i, t}=B A S_{i, t}-N B A S_{i} \\
N B A S_{i}=\left(\sum_{t=-132}^{-6} B A S_{i, t}\right) / 126
\end{gathered}
$$

where $B A S_{i, t}$ is the bid-ask spread on day $t$ associated with event $i, A B A S_{i, t}$ is the abnormal bid-ask spread on day $t$ associated with event $i$, and $N B A S_{i}$ is the average normal bid-ask spread associated with event $i$ as calculated over the estimation period. In the forthcoming section, we present the results of our formal testing of the crosssectional average abnormal bid-ask spreads:

$$
\overline{A B A S}_{t}=\left(\frac{1}{74} \sum_{i=1}^{74} A B A S_{i, t}\right), t=-5, \ldots,+5 .
$$

\footnotetext{
${ }^{4}$ Benninga (2008) recommends a 252-day estimation period or longer, but the author also states that the minimum requirement is 126 days. In this paper we opt for the minimum requirement in order to preserve the sample size. A longer estimation period would narrow down the sample size to 71 because of the event overlapping. As a robustness test we perform the analysis adopting a $252-$ day estimation period and the results do not change. Results available from the authors on request.
} 
In order to investigate which factors affect the bid-ask spread and whether the impact of the announcement is larger for specific industries or not, we also implement a regression analysis. The empirical model is presented in Equation (3):

$$
\begin{aligned}
\text { ABAS }_{i, 0}=\beta_{0} & +\beta_{1} \text { Price }_{i, 0}+\beta_{2} \text { Turnover }_{i, 0}+\beta_{3} \text { Var }_{i, 0}+\beta_{4} \text { MarketCap }_{i, 0} \\
& +\beta_{5} \text { BMRatio }_{i, 0}+\beta_{6} \text { Leverage }_{i, 0}+\beta_{7} \text { Ownership }_{i, 0} \\
& +\beta_{8} \text { BreachScale }_{i, 0}+\beta_{9} \text { PriorBreach }+\beta_{10}^{\prime} \text { BreachType } \\
& +\beta_{11}^{\prime} \text { Industry }_{\varepsilon}
\end{aligned}
$$

The dependent variable $(A B A S)$ is the abnormal bid-ask spread on the event day (day 0 ). We include four types of independent variables. Firstly, we include some important determinants of the bid-ask spread drawn from the literature (Aitken and Frino, 1996; Aitken, et al., 2004; Glosten and Milgrom, 1985; Gorkittisunthorn et al., 2006; Stoll, 1978). Price is the natural logarithm of the closing price and it proxies for dealer's ordering cost. Turnover is stock daily turnover and it proxies for inventory-holding cost. Var is a measure of the daily stock price volatility and proxies for dealer's inventoryholding risk. Other than order processing and inventory-holding, bid-ask spread might be also positively related to informed trading, which is captured in the intercept term. Secondly, we include control variables for company characteristics such as the natural $\log$ of market capitalisation (MarketCap), the book-to-market ratio (BMRatio), the leverage ratio (Leverage), and the percentage of shares owned by the CEO (Ownership) all measured at the end of the fiscal year prior the breach. Thirdly, in order to control for event characteristics, we include in the regression model the natural logarithm of the number of records breached (BreachScale), and a dummy variable equal to 1 if a firm experienced a data breach before and 0 otherwise (PriorBreach) (Gatzlaff and McCullough 2010). Following Gatzlaff and McCullough (2010), we also consider a set of dummy variables to control for the type of breach, namely Active, Stolen, Lost, and Unknown. Active is a dummy variable equal to 1 if it is evident in the description of the data breach that the intent of the breach was to steal personal data, and 0 otherwise. Stolen is a dummy variable equal to 1 if the description of the data breach reveals that a device containing personal data has been stolen and it is unknown whether the intent of the breach was to steal personal data, and 0 otherwise. Lost is a dummy variable equal to 1 if the description of the data breach reveals that a device containing personal data has been lost or misplaced, and 0 otherwise. All the events which cannot be classified as 
Active, Stolen or Lost are considered to have unknown causes (Unknown) and are used as baseline in our empirical model. We therefore define BreachType $=\{$ Active, Stolen, Lost\}. Fourthly, we control for differential announcement impact among different industries, considering the manufacturing industry (Manufacturing) as baseline. We therefore define the set of sector dummy variables Industry $=\{$ Public, Transportation, Wholesale, Retail, Finance, Services\}, corresponding to the industry sectors set out in Table 3.

To investigate the effect of data breaches on trading volume, we adopt the daily stock turnover for the tests in this paper. Turnover is defined as trading volume divided by outstanding shares. Compared to the raw trading volume, it corrects for the number of outstanding shares so it allows a cleaner interpretation of the results (Chae, 2005). Following Chae (2005), we estimate the abnormal turnover over the analysis period as follows:

$$
\begin{gathered}
\operatorname{ATURN}_{i, t}=\operatorname{TURN}_{i, t} / \operatorname{NTURN}_{i} \\
\operatorname{NTURN}_{i}=\left(\sum_{t=-132}^{-6} \operatorname{TURN}_{i, t}\right) / 126
\end{gathered}
$$

where $T U R N_{i, t}$ is the turnover on day $t$ associated with event $i, A T U R N_{i, t}$ is the abnormal turnover on day $t$ associated with event $i$, and $N T U R N_{i}$ is the average normal turnover associated with event $i$ as calculated over the estimation period.

In the forthcoming section, we present the results of our formal testing of the crosssectional average abnormal turnovers:

$$
\overline{\operatorname{ATURN}}_{t}=\left(\frac{1}{74} \sum_{i=1}^{74} \operatorname{ATURN}_{i, t}\right), t=-5, \ldots,+5 .
$$

To analyse what factors predict change in trading volume and whether the announcement impact is different in different industries we also implement a regression analysis, akin to the bid-ask spread case. Following Chae (2005), we regress the abnormal turnover on information asymmetry, risk and price impact. The resulting empirical model is presented in Equation (6): 


$$
\begin{aligned}
\text { ATURN }_{i, 0}= & \beta_{0} \\
& +\beta_{1} \text { Price }_{i, 0}+\beta_{2} \text { BAS }_{i, 0}+\beta_{3} \text { Var }_{i, 0}+\beta_{4} \text { MarketCap }_{i, 0} \\
& +\beta_{5} \text { BMRatio }_{i, 0}+\beta_{6} \text { Leverage }_{i, 0}+\beta_{7} \text { Ownership }_{i, 0} \\
& +\beta_{8} \text { BreachScale }_{i, 0}+\beta_{9} \text { PriorBreach }+\beta_{10}^{\prime} \text { BreachType } \\
& +\beta_{11}^{\prime} \text { Industry }_{\varepsilon}
\end{aligned}
$$

The dependent variable $(A T U R N)$ is the abnormal turnover on the announcement day (day 0). BAS is the bid-ask on the announcement day. All other variables are as previously defined.

\section{RESUlts}

\subsection{Univariate analysis}

Table 4 provides summary statistics. In particular, it is worth noting three points from this table. First, breached firms in our sample lost, on average, 2.53 percent of their value during the event day and the day following the event. Second, both the abnormal bid-ask spread and the abnormal turnover in the announcement day are, on average, positive. Third, the number of records breached ranges from 11 (Citigroup, October 2, 2006) to 145 million (Ebay, May 21, 2014) so we adopt a log transformation in the regression analysis; furthermore, the average value is highly influenced by very large events so we replicate the regression analysis ${ }^{5}$ excluding the largest (five percent of) events to ensure that our results are not biased by any outliers.

\section{Insert Table 4 here}

Table 5 presents the results of the event study analysis on the daily average abnormal bid-ask spread over the analysis period $(-5,+5)$. It shows a significant and positive impact of data breach announcements on the bid-ask spread on the day of the announcement. The average value is larger than the days before and after the event, with this result being statistically significant at the 1 percent level. This suggests that market dealers widen the spreads following the announcement. This allows us to accept H1(a) since no abnormal trading emerges before the announcements ${ }^{6}$. We equally

\footnotetext{
${ }^{5}$ Results available from the authors on request.

${ }^{6}$ Although a statistically significant impact on bid-ask spread is recorded on day -4 , it is notable that the result is negative, suggesting a tightening, rather than a widening, of the bid-ask spread. No other day prior to the announcement shows any evidence of abnormal behavior. On this basis we conclude that there is no evidence of abnormal behavior prior to the announcement day.
} 
accept H1(b) since the breach impact is positive and statistically significant. However, the effect is very short-lived, indeed lasting only the day of the announcement, showing that the market responds to the announcement efficiently.

\section{Insert Table 5 here}

Table 6 presents the results of the event study analysis on the daily trading volume over the analysis period. In a similar manner to bid-ask spread, the impact is positive and statistically significant, at the 5 percent level, only on the event day. This means that investors trade more on the announcement day only. We may therefore accept H2(a) since no abnormal trading emerges before the announcements ${ }^{7}$. This evidence corroborates our finding based on bid-ask spread and provides us with more confidence that informed trading on the back of data breach events is not a feature of the markets. Similar to before, we accept also H2(b) since the breach impact is positive and statistically significant, while the short-lived nature of the effect confirms that the market responds to the announcement efficiently.

\section{Insert Table 6 here}

To explore our data set further, we move to the H3-set of hypotheses, where we wish to ascertain if the breach size has an effect. The theoretical argument is that large breaches should be associated with larger implicit and explicit costs, and so we may expect that such breaches would have a larger impact than more minor events on both the bid-ask spread, since they create higher uncertainty, and trading volume, since they may cause a more significant drop in share price and investors may be more willing to sell stocks to avoid significant losses. We classify the events as large is they were assigned to the highest size tercile. Then we preform a t-test on the differences in abnormal bid-ask spread and trading volume between the two subsamples (i.e. large breaches vs small/medium breaches). Table 7 reports the results of the analysis. The results suggest that large breaches do indeed have a larger positive and significant (5 percent level) impact on the bid-ask spread than medium and small sized breaches, but not on trading volume. The results lead us to accept $\mathrm{H} 3$ (a) and to reject $\mathrm{H} 3(\mathrm{~b})$.

\section{Insert Table 7 here}

\footnotetext{
${ }^{7}$ Although a statistically significant impact on trading volume is recorded on day -5 , no other day prior to the announcement shows any evidence of abnormal behavior. On this basis we conclude that there is no evidence of abnormal behavior prior to the announcement day.
} 
In order to investigate whether a differential impact exists depending on breach type, as per the set of hypotheses $\mathrm{H} 4$, and following the t-testing approach for breach size, we classify the following group pairings for analysis: Active v. Non-Active; Stolen $v$. NonStolen; Lost v. Non-Lost; and Unknown v. Known according to the definitions provided above. Table 8 (Panel C) shows that, when compared to other events, those classified as Lost have a larger and statistically significant impact on both the bid-ask spread and the turnover (5 percent significance levels); in contrast those classified as Stolen (Panel B) have a larger and significant impact on turnover only (10 percent significance level). With only the Unknown and Known groups showing no statistically significant differences, we can viably reject $\mathrm{H} 4$ (a) and $\mathrm{H} 4$ (b) and come to the conclusion that the type of data breach is an important factor in determining the response of the market to the emerging news on the data breach announcement day.

\section{Insert Table 8 here}

\subsection{Multivariate analysis}

Going beyond the mere detection of a significant impact of data breach announcements on the bid-ask spread and trading volume, we aim in this section to identify which factors influence such impacts. Table 9 reports the results of the regression model presented in Equation (3). Panel A shows that the abnormal bid-ask spread on the event day is positively related to stock price (Price) and volatility (Var). These results suggest that the bid-ask spread is positively related to dealers' ordering cost (Price) and to inventory-holding risk (Var), while it is not affected by information asymmetry (embedded in the intercept term) and by inventory-holding time (Turnover). Panel B to Panel E present the results of the extended version of the model presented in Panel A, which control for any dependence on firm, event or industry characteristics. Results show that firms in the service industry (Service) tend to have a larger bid-ask spread reaction to the announcement. All other control variables are not significant showing that the change in bid-ask spread is not linked to firms or event characteristics.

\section{Insert Table 9 here}

Table 10 presents the results of the regression analysis on abnormal turnover following the model presented in Equation (6). Panel A shows that the abnormal trading volume on the event day is positively and significantly related to stock price (Price) and information asymmetry $(B A S)$. Panel B to Panel E show that larger firms (MarketCap) 
experience larger abnormal turnover on the announcement day. Results in Panel E also show that the announcement of a data breach made by a firm operating in the wholesale trade industry (Wholesale) tends to trigger a larger turnover reaction.

\section{Insert Table 10 here}

\section{Conclusions}

We fill an important gap in the literature by means of analysing the impact of data breach announcements on market activity. Adopting an event study methodology, we find evidence of a short-term effect of data breach announcements on bid-ask spread and trading volume. Interestingly, no abnormal trading activity emerges before the announcement, confirming that these types of events are not being exploited by informed market participants. Our results also show that market dealers widen the bidask spread because of trading costs and inventory-holding risk, and that the trading volume on the announcement day is positively related to information asymmetry and trading risk.

Our results will be of interest and indeed valuable to a number of stakeholders. First and foremost, our evidence should provide investors with reassurance that data breach events seem not to be exploited by informed traders in the run up to public announcements. This has important implication for investment strategy. Secondary to this, regulators will be interested in the evidence for the absence of abnormal trading before data breach announcements. This provides some indirect evidence to the efficacy of the security breach notification laws that have been introduced across the United States in recent years.

Our study should motivate further research into the understudied area of data breaches. A key limitation of our study is that the use of daily data does not allow us to separate buying and selling activity, which might follow different patterns over the analysis period. This presents an immediate future direction for this research. 


\section{References}

Abbasi, A., Sarker, S., \& Chiang, R. H. 2016. Big Data Research in Information Systems: Toward an Inclusive Research Agenda. Journal of the Association for Information Systems 17.

Admati, A. R., \& Pfleiderer, P. 1988. A theory of intraday patterns: Volume and price variability. Review of Financial studies 1, 3-40.

Affleck-Graves, J., Callahan, C. M., \& Ramanan, R. 2000. Detecting abnormal bid-ask spread: a comparison of event study methods. Review of Quantitative Finance and Accounting 14, 45-65.

Affleck-Graves, J., Callahan, C. M., \& Chipalkatti, N. 2002. Earnings predictability, information asymmetry, and market liquidity. Journal of Accounting Research 40, $561-583$.

Aitken, M., \& Frino, A. 1996. The determinants of market bid ask spreads on the australian stock exchange: Cross-sectional analysis. Accounting \& Finance 36, 5163.

Aitken, M. J., Frino, A., Hill, A. M., \& Jarnecic, E. 2004. The impact of electronic trading on bid-ask spreads: Evidence from futures markets in Hong Kong, London, and Sydney. The Journal of Futures Markets 24, 675.

Arend, R. J. 2004. The Definition of Strategic Liabilities, and their Impact on Firm Performance*. Journal of Management Studies 41, 1003-1027.

Augustin, P., Brenner, M., \& Subrahmanyam, M. G. 2015. Informed options trading prior to M\&A announcements: Insider trading? Available at SSRN 2441606.

Benston, G., \& Hagerman, R. 1974. Determinants of bid-ask spread in the over-thecounter market. The Journal of Financial Economics 1 (3): 353364.

Benninga, S. 2008. Financial modelling, Third Ed. MIT Press Books.

Bharadwaj, A. S., Bharadwaj, S. G., \& Konsynski, B. R. 1999. Information technology effects on firm performance as measured by Tobin's q. Management science 45, 1008-1024.

Black, F. 1986. Noise. The journal of finance 41, 528-543.

Blankespoor, E., Miller, G. S., \& White, H. D. 2014. The Role of Dissemination in Market Liquidity: Evidence from Firms' Use of Twitter ${ }^{\mathrm{TM}}$. The Accounting Review 89, 79-112.

Bushee, B. J., Core, J. E., Guay, W., \& Hamm, S. J. 2010. The role of the business press as an information intermediary. Journal of Accounting Research 48, 1-19. 
Campbell, K., Gordon, L. A., Loeb, M. P., \& Zhou, L. 2003. The economic cost of publicly announced information security breaches: empirical evidence from the stock market. Journal of Computer Security 11, 431-448.

Cavusoglu, H., Mishra, B., \& Raghunathan, S. 2004. The effect of internet security breach announcements on market value: Capital market reactions for breached firms and internet security developers. International Journal of Electronic Commerce 9, 70-104.

Chae, J. 2005. Trading volume, information asymmetry, and timing information. The journal of finance $60,413-442$.

Chan, K., Ge, L., \& Lin, T.-C. 2015. Informational content of options trading on acquirer announcement return. Journal of Financial and Quantitative Analysis 50, 1057-1082.

Charette, R. N., Adams, K. M., \& White, M. B. 1997. Managing risk in software maintenance. IEEE Software 14, 43.

Chen, H., Chiang, R. H., \& Storey, V. C. 2012. Business Intelligence and Analytics: From Big Data to Big Impact. MIS quarterly 36, 1165-1188.

Chen, K., \& Wu, L. 2001. Introduction and expiration effects of derivative equity warrants in Hong Kong. International Review of Financial Analysis 10, 37-52.

Coller, M., \& Yohn, T. L. 1997. Management forecasts and information asymmetry: An examination of bid-ask spreads. Journal of accounting research 35, 181-191.

Copeland, T. E., \& Galai, D. 1983. Information effects on the bid-ask spread. the Journal of Finance 38, 1457-1469.

Corwin, S. A., \& Schultz, P. 2012. A simple way to estimate bid-ask spreads from daily high and low prices. The Journal of Finance 67, 719-760.

Deloitte. 2016. Cyber security: The changing role of the Board and the Audit Committee. in, Deloitte Touche Tohmatsu Limited.

Demsetz, H. 1968. The cost of transacting. The quarterly journal of economics, 33-53.

Dennis, A., Wixom, B. H., \& Tegarden, D. 2015. Systems analysis and design: An object-oriented approach with UML. John Wiley \& Sons.

Easley, D., de Prado, M. L., \& O'Hara, M. 2016. Discerning information from trade data. Journal of Financial Economics 120, 269-285.

Fama, E. F. 1970. Efficient capital markets: A review of theory and empirical work*. The journal of Finance 25, 383-417. 
Foster, F. D., \& Viswanathan, S. 1990. A theory of the interday variations in volume, variance, and trading costs in securities markets. Review of financial Studies 3, 593-624.

Franz, D. R., Rao, R. P., \& Tripathy, N. 1995. Informer Trading risk and bid-ask spread changes around open market stock repurchases in the Nasdaq market. Journal of Financial Research 18, 311-327.

Frino, A., Jones, S., \& Wong, J. B. 2007. Market behaviour around bankruptcy announcements: evidence from the Australian Stock Exchange. Accounting \& Finance 47, 713-730.

FTC. 2009. Consumer Data Broker ChoicePoint Failed to Protect Consumers' Personal Data, Left Key Electronic Monitoring Tool Turned Off for Four Months. in, Federal Trade Commission.

Garg, A., Curtis, J., \& Halper, H. 2003. Quantifying the financial impact of IT security breaches. Information Management \& Computer Security 11, 74-83.

Gatzlaff, K. M., \& McCullough, K. A. 2010. The effect of data breaches on shareholder wealth. Risk Management and Insurance Review 13, 61-83.

George, T. 2016. Cyber Security Oversight: Why it Belongs in the Board Room. in, Vol. 2016, Security Week.

Glosten, L. R., \& Milgrom, P. R. 1985. Bid, ask and transaction prices in a specialist market with heterogeneously informed traders. Journal of financial economics 14 , 71-100.

Goldstein, J., Chernobai, A., \& Benaroch, M. 2011. An event study analysis of the economic impact of IT operational risk and its subcategories. Journal of the Association for Information Systems 12, 606 .

Gorkittisunthorn, M., Jumreornvong, S., \& Limpaphayom, P. 2006. Insider ownership, bid-ask spread, and stock splits: Evidence from the Stock Exchange of Thailand. International Review of Financial Analysis 15, 450-461.

Hagigi, M., Kluger, B. D., \& Shields, D. 1993. Auditor change announcements and dispersion of investor expectations. Journal of Business Finance \& Accounting 20, 787-802.

Holden, Craig W. "New low-frequency spread measures." Journal of Financial Markets 12.4 (2009): 778-813.

Hollander, H., \& Prokop, J. 2015. Stock price effects of asset securitization: The case of liquidity facility providers. The Quarterly Review of Economics and Finance 57, 147-160. 
Hovav, A., \& D'Arcy, J. 2003. The Impact of Denial-of-Service Attack Announcements on the Market Value of Firms. Risk Management and Insurance Review 6, 97-121.

Hulme, G. V. 2015. Top executives and cybersecurity: a fickle relationship? in, Vol. 2016, CSO.

Ko, Myung, Kweku-Muata Osei-Bryson, and Carlos Dorantes. "Investigating the impact of publicly announced information security breaches on three performance indicators of the breached firms." Information Resources Management Journal 22.2 (2009): 1.

Koch, A., Ruenzi, S., \& Starks, L. 2016. Commonality in liquidity: a demand-side explanation. Review of Financial Studies, hhw026.

Kotha, K. K., Ramabhadran, S. T., \& Yadav, P. K. 2010. Hiding Behind the Veil: Informed Traders and Pre-Trade Opacity. Available at SSRN 1572201.

Krinsky, I., \& Lee, J. 1996. Earnings announcements and the components of the bid-ask spread. The Journal of Finance 51, 1523-1535.

Krudy, E. 2012. Websites of exchanges Nasdaq, BATS hit in online attack. in, Vol. 2016, Reuters.

Kyle, A. S. 1985. Continuous auctions and insider trading. Econometrica: Journal of the Econometric Society, 1315-1335.

LaValle, S., Lesser, E., Shockley, R., Hopkins, M. S., \& Kruschwitz, N. 2011. Big data, analytics and the path from insights to value. MIT sloan management review 52, 21.

Lee, C. M., Mucklow, B., \& Ready, M. J. 1993. Spreads, depths, and the impact of earnings information: An intraday analysis. Review of Financial Studies 6, 345374.

Lesmond, David A., Joseph P. Ogden, and Charles A. Trzcinka. "A new estimate of transaction costs." Review of Financial Studies 12.5 (1999): 1113-1141.

Lo, A. W., \& Wang, J. 2000. Trading volume: definitions, data analysis, and implications of portfolio theory. Review of Financial Studies 13, 257-300.

McLean, R. D., \& Pontiff, J. 2016. Does academic research destroy stock return predictability? The Journal of Finance 71, 5-32.

Michels, J. 2016. Disclosure versus recognition: Inferences from subsequent events. Journal of Accounting Research.

Milgrom, P., \& Stokey, N. 1982. Information, trade and common knowledge. Journal of Economic Theory 26, 17-27. 
Minelli, M., Chambers, M., \& Dhiraj, A. 2012. Big data, big analytics: emerging business intelligence and analytic trends for today's businesses. John Wiley \& Sons.

Paquette, S., Jaeger, P. T., \& Wilson, S. C. 2010. Identifying the security risks associated with governmental use of cloud computing. Government Information Quarterly 27, 245-253.

Pinder, S. 2003. An empirical examination of the impact of market microstructure changes on the determinants of option bid-ask spreads. International Review of Financial Analysis 12, 563-577.

Ponemon. 2015. 2015 Cost of Data Breach Study: Global Analysis. in, Ponemon Institute LLC.

Roll, Richard. "A simple implicit measure of the effective bid-ask spread in an efficient market." The Journal of Finance 39.4 (1984): 1127-1139.

Romanosky, S., Hoffman, D., \& Acquisti, A. 2014. Empirical analysis of data breach litigation. Journal of Empirical Legal Studies 11, 74-104.

Savitz, E. 2012. Nasdaq Web Site Shut Down By Denial Of Service Attacks. in Forbes, Forbes.

SEC. 2014. Cybersecurity Roundtable. in, Vol. 2016, U.S. Securities and Exchange Commission.

SEC. 2016. Cybersecurity and the SEC. in, Vol. 2016, U.S. Securities and Exchange Commission.

Stoll, H. R. 1978. The pricing of security dealer services: An empirical study of NASDAQ stocks. The journal of finance 33, 1153-1172.

Venkatesh, P., \& Chiang, R. 1986. Information Asymmetry and the Dealer's Bid-Ask Spread: A Case Study of Earnings and Dividend Announcements. The Journal of Finance 41, 1089-1102.

Verizon. 2015. 2015 Data Breach Investigations Report. in, Verizon Enterprise Solutions.

Wang, J. 1994. A model of competitive stock trading volume. Journal of political Economy, 127-168.

Winn, Jane K. "Are" Better" Security Breach Notification Laws Possible?." Berkeley Technology Law Journal 24.3 (2009): 1133-1165. 
Table 1

Data set and applied filters

\begin{tabular}{rrr}
\hline \multicolumn{1}{c}{ Filters } & \multicolumn{2}{c}{ Number of events } \\
\hline Events reported by Privacy Rights Clearinghouse (2005- & Deleted & Remaining \\
Non-publicly traded firms & 4,152 & 4,483 \\
Events with possible confounding announcements & 58 & 331 \\
Zero or unknown number of records breached & 149 & 273 \\
Data breach in the estimation period & 14 & 124 \\
Missing data & 36 & 110 \\
\hline Final Sample & & 74
\end{tabular}

This table reports the number of observations deleted and remaining after each applied filter.

\section{Table 2}

Frequency of data breaches per year

\begin{tabular}{ccc}
\hline Year & Number of events & Percentage \\
\hline 2005 & 2 & 2.70 \\
2006 & 14 & 18.92 \\
2007 & 9 & 12.16 \\
2008 & 5 & 6.76 \\
2009 & 3 & 4.05 \\
2010 & 7 & 9.46 \\
2011 & 11 & 14.86 \\
2012 & 7 & 9.46 \\
2013 & 8 & 10.81 \\
2014 & 8 & 10.81 \\
\hline Total & 74 & 100 \\
\hline
\end{tabular}

This table reports the number of events and relative percentages for each year. 
Table 3

Frequency of data breaches per industry

\begin{tabular}{rccc} 
Industry & SIC Codes & $\begin{array}{c}\text { Number of } \\
\text { events }\end{array}$ & Percentage \\
\hline Manufacturing & $20-39$ & 14 & 18.92 \\
Transportation & $40-49$ & 8 & 10.81 \\
Wholesale & $50-51$ & 2 & 2.70 \\
Retail & $52-59$ & 17 & 22.97 \\
Finance & $60-67$ & 24 & 32.43 \\
Services & $70-89$ & 8 & 10.81 \\
Public Administration & $91-99$ & 1 & 1.35 \\
\hline Total & & 74 & 100
\end{tabular}

This table reports the number of events and relative percentages for each industry. The industry classification is based on the 2-digit SIC codes category as reported on http://siccode.com/.

Table 4

Summary statistics

\begin{tabular}{|c|c|c|c|c|c|}
\hline Variable & Mean & Dev & $25 \%$ & $50 \%$ & $75 \%$ \\
\hline CARs $(0,1)$ & -0.025 & 0.033 & -0.043 & -0.019 & -0.002 \\
\hline BAS & 0.026 & 0.012 & 0.016 & 0.024 & 0.036 \\
\hline ABAS & & 0.011 & -0.005 & 0.000 & 0.011 \\
\hline TURN & 0.009 & 0.004 & -0.002 & 0.000 & 0.003 \\
\hline ATURN & 0.137 & 0.558 & -0.255 & 0.033 & 0.265 \\
\hline Price & 3.397 & 0.841 & 2.967 & 3.414 & 3.853 \\
\hline Var & 0.021 & 0.016 & 0.009 & 0.017 & 0.030 \\
\hline MarketCap & 9.964 & 1.688 & 8.900 & 9.864 & 11.454 \\
\hline BMRatio & 0.567 & 0.639 & 0.299 & 0.451 & 0.744 \\
\hline Leverage & 0.182 & 0.160 & 0.000 & 0.185 & 0.301 \\
\hline BreachScale & 8.948 & 3.794 & 6.252 & 8.517 & 11.318 \\
\hline Ownership & 0.333 & 2.348 & 0.000 & 0.000 & 0.000 \\
\hline PriorBreach & 0.427 & & & & \\
\hline
\end{tabular}


This table reports summary statistics of cumulative abnormal returns estimated through Fama and French three factors model (CARs), bid-ask spread on the announcement day (BAS), abnormal bid-ask spread on the announcement day (ABAS), stock turnover on the announcent day (TURN), abnormal stock turnover on the announcent day (ATURN), natural logarithm of the closing price on the announcement day (Price), stock price volatility on the announcement day (Var), natural logarithm of the market capitalisation at the end of the fiscal year prior to the breach (MarketCap), book-to-market ratio at the end of the fiscal year prior to the breach (BMRatio), leverage ratio (Leverage), natural logarithm of the number of records breached (BreachScale), the percentage of CEO ownership (Ownership), and a dummy variable equal to 1 if a firm expeprienced a breach in the past, 0 otherwise (PriorBreach). Descriptive statistics include mean, standard deviation, first quartile (25\%), median (50\%), and third quartile $(75 \%)$.

Table 5

Daily abnormal bid-ask spread

\begin{tabular}{|c|c|c|c|}
\hline Day & ABAS & \multicolumn{2}{|c|}{ p-value } \\
\hline-5 & -0.001 & 0.116 & \\
\hline-4 & -0.002 & 0.041 & $* *$ \\
\hline-3 & 0.001 & 0.299 & \\
\hline & 0.001 & 0.131 & \\
\hline & 0.001 & 0.293 & \\
\hline & 0.003 & 0.005 & $* * *$ \\
\hline 1 & 0.001 & 0.327 & \\
\hline 2 & 0.001 & 0.293 & \\
\hline 3 & 0.000 & 0.665 & \\
\hline 4 & 0.000 & 0.776 & \\
\hline 5 & -0.001 & 0.509 & \\
\hline
\end{tabular}

This table reports the daily average abnormal bid-ask spread (ABAS), together with the p-values associated with the t-tests on their significance $(\mathrm{H} 0: \mathrm{ABAS}=0)$.

$*, * *, * * *$ Significance at 10,5 and 1 per cent levels, respectively.

\section{Table 6}

Daily abnormal turnover

\begin{tabular}{cccc}
\hline Day & ATURN & p-value & \\
\hline-5 & 0.001 & 0.041 & $* *$ \\
-4 & 0.000 & 0.998 & \\
-3 & 0.001 & 0.225 &
\end{tabular}




\begin{tabular}{ccc}
-2 & 0.000 & 0.495 \\
-1 & 0.000 & 0.724 \\
0 & 0.001 & $0.023 \quad * *$ \\
1 & 0.001 & 0.126 \\
2 & 0.000 & 0.839 \\
3 & 0.000 & 0.788 \\
4 & 0.000 & 0.803 \\
5 & 0.000 & 0.913 \\
\hline
\end{tabular}

This table reports the daily average abnormal stock turnover (ATURN), together with the p-values associated with the t-tests on their significance (H0: ATURN=0).

$*, * *, * * *$ Significance at 10,5 and 1 per cent levels, respectively.

\section{Table 7}

Data breach size and market reaction

\begin{tabular}{rcccc}
\hline Variable & Large & Small-Medium & p-value & \\
\hline ABAS & 0.007 & 0.002 & 0.034 & $* *$ \\
ATURN & 0.001 & 0.001 & 0.662
\end{tabular}

This table reports the mean values of abnormal bid-ask spread (Panel A) and abnormal stock turnover (Panel B) on the announcement day by breach size, and the p-values associated with the t-tests on the significance of the difference between the two subsamples (H0: difference equal to 0). Events classification is based on tercile thresholds with large breaches falling in the third tercile.

$*, * *, * * *$ Significance at 10,5 and 1 per cent levels, respectively.

\section{Table 8}

Data breach type and market reaction

\begin{tabular}{rccc}
\hline \multicolumn{4}{c}{ Panel A: Data Breaches caused by active attacks } \\
\hline Variable & Active & Non-Active & p-value \\
\hline ABAS & 0.004 & 0.003 & 0.744 \\
AVOL & 0.001 & 0.001 & 0.874 \\
$\mathrm{~N}$ & 37 & 37 & \\
\hline
\end{tabular}

Panel B: Data Breaches caused by stolen devices

\begin{tabular}{rcccc}
\hline Variable & Stolen & Non-Stolen & p-value \\
\hline ABAS & 0.002 & 0.004 & 0.416 & \\
AVOL & 0.000 & 0.001 & $0.089 *$
\end{tabular}


Panel C: Data Breaches caused by lost devices

\begin{tabular}{rccrl}
\hline \multicolumn{1}{l}{ Variable } & Lost & Non-Lost & p-value & \\
\hline ABAS & 0.011 & 0.002 & 0.027 & $* *$ \\
AVOL & 0.004 & 0.000 & 0.023 & $* *$ \\
N & 10 & 64 & & \\
\hline
\end{tabular}

Panel D: Data Breaches whose causes are unknown/undisclosed

\begin{tabular}{rccc}
\hline \multicolumn{1}{c}{ Variable } & Unknown & Known & p-value \\
\hline ABAS & 0.013 & 0.003 & 0.215 \\
AVOL & 0.001 & 0.001 & 0.821 \\
$\mathrm{~N}$ & 7 & 67 &
\end{tabular}

This table reports the mean values of abnormal bid-ask spread (Panel A) and abnormal stock turnover (Panel B) on the announcement day by breach type, and the p-values associated with the t-tests on the significance of the difference between the subsamples (H0: difference equal to 0). Event classification is based on Gatzlaff and McCullough (2010).

$*, * *, * * *$ Significance at 10,5 and 1 per cent levels, respectively.

\section{Table 9}

Regression analysis: abnormal bid-ask spread

\begin{tabular}{|c|c|c|c|c|c|c|c|c|c|c|}
\hline Variable & Panel A & & Panel B & & Panel $C$ & & Panel D & & Panel E & \\
\hline \multirow{2}{*}{ Intercept } & -0.001 & & -0.002 & & 0.000 & & -0.002 & & -0.003 & \\
\hline & $(0.913)$ & & $(0.920)$ & & $(0.997)$ & & $(0.888)$ & & $(0.872)$ & \\
\hline \multirow{2}{*}{ Price } & 0.003 & ** & 0.002 & & 0.002 & & 0.001 & & 0.001 & \\
\hline & $(0.047)$ & & $(0.169)$ & & $(0.214)$ & & $(0.286)$ & & $(0.401)$ & \\
\hline \multirow{2}{*}{ Turnover } & 0 & & 0.003 & & 0.002 & & 0.002 & & 0.001 & \\
\hline & $(0.475)$ & & $(0.267)$ & & $(0.284)$ & & $(0.418)$ & & $(0.572)$ & \\
\hline \multirow{2}{*}{ Var } & 0.313 & $* * *$ & 0.289 & $* * *$ & 0.288 & $* * *$ & 0.303 & $* * *$ & 0.327 & $* * *$ \\
\hline & $(0.001)$ & & $(0.001)$ & & $(0.002)$ & & $(0.001)$ & & $(0.001)$ & \\
\hline \multirow{2}{*}{ MarketCap } & & & 0.001 & & 0.001 & & 0.001 & & 0.001 & \\
\hline & & & $(0.414)$ & & $(0.456)$ & & $(0.418)$ & & $(0.238)$ & \\
\hline \multirow{2}{*}{ BMRatio } & & & -0.003 & & -0.003 & & -0.003 & & -0.003 & \\
\hline & & & $(0.191)$ & & $(0.190)$ & & $(0.180)$ & & $(0.240)$ & \\
\hline \multirow{2}{*}{ Leverage } & & & -0.004 & & -0.004 & & -0.002 & & -0.006 & \\
\hline & & & $(0.629)$ & & $(0.606)$ & & $(0.793)$ & & $(0.612)$ & \\
\hline \multirow{2}{*}{ Ownership } & & & -0.001 & & -0.001 & & -0.001 & & 0.000 & \\
\hline & & & $(0.291)$ & & $(0.252)$ & & $(0.356)$ & & $(0.958)$ & \\
\hline \multirow{2}{*}{ BreachScale } & & & & & 0.000 & & 0.000 & & 0.000 & \\
\hline & & & & & $(0.603)$ & & $(0.618)$ & & $(0.795)$ & \\
\hline PriorBreach & & & & & 0.000 & & -0.001 & & 0.000 & \\
\hline
\end{tabular}


Active

Stolen

Public

Services

This table reports the results of the regression analysis for the model presented in Equation (3). The dependent variable is the abnormal bid-ask spread on the announcement day (ABAS) while the independent variables are: natural logarithm of closing price (Price); stock turnover on the announcement day (Turnover); stock price volatility on the announcement day (Var); natural logarithm of the market capitalisation at the end of the fiscal year prior to the breach (MarketCap); book-to-market ratio at the end of the fiscal year prior to the the breach (BMRatio); leverage ratio (Leverage); the percentage of CEO ownership (Ownership); natural logarithm of the number of records breached (BreachScale); a dummy variable equal to 1 if a firm experienced a breach in the past, 0 otherwise (PriorBreach); dummy variables for the type of breach (Active, Stolen, Lost); dummy varibales for different industries (Public, Transportation, Wholesale, Retail, Finance, Services). OLS regressions with year fixed-effect and hetheroskedasticity-consistent standard errors. P-values reported in parethesis. *,**,*** Significance at 10 , 5 and 1 per cent levels, respectively.

\section{Table 10}

Regression analysis: abnormal turnover

\begin{tabular}{|c|c|c|c|c|c|}
\hline Variable & Panel A & Panel B & Panel C & Panel D & Panel E \\
\hline & -0.006 & $-0.010 \quad * *$ & $-0.011 \quad * *$ & $-0.009 \quad * *$ & $-0.009 *$ \\
\hline & $(0.105)$ & $(0.017)$ & $(0.020)$ & $(0.049)$ & $(0.058)$ \\
\hline
\end{tabular}




\begin{tabular}{|c|c|c|c|c|c|c|c|c|c|}
\hline Price & $\begin{array}{r}0.001 \\
(0.084)\end{array}$ & $*$ & $\begin{array}{r}0.000 \\
(0.509)\end{array}$ & & $\begin{array}{r}0.000 \\
(0.616)\end{array}$ & & $\begin{array}{r}0.000 \\
(0.698)\end{array}$ & $\begin{array}{r}0.000 \\
(0.813)\end{array}$ & \\
\hline Bas & $\begin{array}{r}0.114 \\
(0.032)\end{array}$ & $* *$ & $\begin{array}{r}0.125 \\
(0.020)\end{array}$ & $* *$ & $\begin{array}{r}0.122 \\
(0.024)\end{array}$ & $* *$ & $\begin{array}{r}0.114 \text { ** } \\
(0.036)\end{array}$ & $\begin{array}{r}0.092 \\
(0.069)\end{array}$ & $*$ \\
\hline Var & $\begin{array}{r}0.052 \\
(0.165)\end{array}$ & & $\begin{array}{r}0.045 \\
(0.230)\end{array}$ & & $\begin{array}{r}0.050 \\
(0.192)\end{array}$ & & $\begin{array}{r}0.052 \\
(0.185)\end{array}$ & $\begin{array}{r}0.076 \\
(0.120)\end{array}$ & \\
\hline MarketCap & & & $\begin{array}{r}0.001 \\
(0.038)\end{array}$ & $* *$ & $\begin{array}{r}0.001 \\
(0.022)\end{array}$ & $* *$ & $\begin{array}{l}0.001 \\
(0.032)\end{array}$ & $\begin{array}{r}0.001 \\
(0.032)\end{array}$ & $* *$ \\
\hline BMRatio & & & $\begin{array}{l}-0.001 \\
(0.317)\end{array}$ & & $\begin{array}{l}-0.001 \\
(0.268)\end{array}$ & & $\begin{array}{l}-0.001 \\
(0.282)\end{array}$ & $\begin{array}{l}-0.001 \\
(0.340)\end{array}$ & \\
\hline Leverage & & & $\begin{array}{r}0.002 \\
(0.590)\end{array}$ & & $\begin{array}{c}0.001 \\
(0.721)\end{array}$ & & $\begin{array}{r}0.001 \\
(0.854)\end{array}$ & $\begin{array}{r}0.003 \\
(0.601)\end{array}$ & \\
\hline Ownership & & & $\begin{array}{r}0.000 \\
(0.898)\end{array}$ & & $\begin{array}{r}0.000 \\
(0.971)\end{array}$ & & $\begin{array}{r}0.000 \\
(0.988)\end{array}$ & $\begin{array}{l}-0.002 \\
(0.126)\end{array}$ & \\
\hline BreachScale & & & & & $\begin{array}{r}0.000 \\
(0.592)\end{array}$ & & $\begin{array}{r}0.000 \\
(0.490)\end{array}$ & $\begin{array}{r}0.000 \\
(0.339)\end{array}$ & \\
\hline PriorBreach & & & & & $\begin{array}{l}-0.001 \\
(0.335)\end{array}$ & & $\begin{array}{r}-0.002 \\
(0.307)\end{array}$ & $\begin{array}{l}-0.001 \\
(0.444)\end{array}$ & \\
\hline Active & & & & & & & $\begin{array}{l}-0.001 \\
(0.739)\end{array}$ & $\begin{array}{l}-0.001 \\
(0.805)\end{array}$ & \\
\hline Stolen & & & & & & & $\begin{array}{c}-0.002 \\
(0.318)\end{array}$ & $\begin{array}{l}-0.002 \\
(0.400)\end{array}$ & \\
\hline Lost & & & & & & & $\begin{array}{r}0.001 \\
(0.736)\end{array}$ & $\begin{array}{l}-0.001 \\
(0.733)\end{array}$ & \\
\hline Public & & & & & & & & $\begin{array}{r}0.045 \\
(0.118)\end{array}$ & \\
\hline Transport & & & & & & & & $\begin{array}{r}0.000 \\
(0.865)\end{array}$ & \\
\hline Wholesale & & & & & & & & $\begin{array}{r}0.006 \\
(0.082)\end{array}$ & $*$ \\
\hline Retail & & & & & & & & $\begin{array}{r}0.001 \\
(0.536)\end{array}$ & \\
\hline Finance & & & & & & & & $\begin{array}{r}0.001 \\
(0.563)\end{array}$ & \\
\hline Services & & & & & & & & $\begin{array}{r}0.004 \\
(0.083)\end{array}$ & $*$ \\
\hline Year FE & Yes & & Yes & & Yes & & Yes & Yes & \\
\hline F-Stat & 1.99 & & 1.90 & & 1.72 & & 1.87 & 1.91 & \\
\hline Adjusted-R ${ }^{2}$ & 0.14 & & 0.16 & & 0.15 & & 0.16 & 0.18 & \\
\hline $\mathrm{N}$ & 74 & & 74 & & 74 & & 74 & 74 & \\
\hline
\end{tabular}


This table reports the results of the regression analysis for the model presented in Equation (6). The dependent variable is the abnormal stock turnover on the announcement day (ATURN) while the independent variables are: natural logarithm of closing price (Price); stock turnover on the announcement day (Turnover); stock price volatility on the announcement day (Var); natural logarithm of the market capitalisation at the end of the fiscal year prior to the breach (MarketCap); book-to-market ratio at the end of the fiscal year prior to the the breach (BMRatio); leverage ratio (Leverage); the percentage of CEO ownership (Ownership); natural logarithm of the number of records breached (BreachScale); a dummy variable equal to 1 if a firm experienced a breach in the past, 0 otherwise (PriorBreach); dummy variables for the type of breach (Active, Stolen, Lost); dummy varibales for different industries (Public, Transportation, Wholesale, Retail, Finance, Services). OLS regressions with year fixed-effect and hetheroskedasticity-consistent standard errors. P-values reported in parethesis. ***,*** Significance at 10, 5 and 1 per cent levels, respectively. 
The Effect of Data Breach Announcements Beyond The Stock Price: Empirical Evidence on Market Activity

\section{Highlights}

- Investigate effect of data breach announcements on market activity, i.e. bid-ask spread and trading volume.

- Investigate data breach announcements as a potential source of asymmetric information

- Data breach announcements found to have positive announcement day effect on market activity.

- No abnormal informed trading evidenced before data breach announcements

- Data breach sizes and type found to be factors in response to data breach announcements. 